\title{
Genetic Variability, Heritability for Late leaf Spot tolerance and Productivity Traits in a Recombinant Inbred Line Population of Groundnut (Arachis hypogaea L.)
}

\author{
Padmaja $\mathrm{D}^{1}$, Brahmeswara Rao ${ }^{2}$, Eswari $^{3}$ K. B and S. Madhusudhan Reddy ${ }^{4}$ \\ ${ }^{1324}$ Department of Genetics and Plant breeding \\ Acharya N. G. Ranga Agricultural University, College of Agriculture, Rajendra nagar, Hyd-30, India
}

\begin{abstract}
One hundred and six recombinant inbred lines (RILs) from JL $24 \times$ ICG 11337 of groundnut (Arachis hypogaea L.) were evaluated for late leaf spot (LLS), yield and its component traits to study for the various genetic parameters viz., magnitude of genotypic, phenotypic variation, heritability and genetic advance as per cent of mean. Highly significant variation was observed for late leaf spot, yield and other component traits. The RIL population showed high range of expression transcending the limits of parental values for some important traits like mature pods / plant, total pods / plant, mature seeds / plant, 100- seed weight, haulm weight / plant and pod yield / plant. High values of PCV, GCV, heritability and genetic advance as per cent of mean in respect of LLS score at 75, LLS score at 90 DAS, 100- seed weight and haulm weight / plant. It was observed that selection for these traits would be useful in the genetic improvement of these traits. Based on mean performance of RILs for group of traits superior lines were selected for LLS tolerance with early maturity, yield and its component traits.
\end{abstract}

Key words: Groundnut, Recombinant inbred lines, Variability, Heritability, Late Leaf Spot and pod yield / plant.

\section{Introduction}

Groundnut (Arachis hypogaea L.) is an important annual oilseed legume crop, valued as a rich source of protein, minerals and vitamins. It is the major oilseed crop in India and in Andhra Pradesh. India ranks second in groundnut production after China with an area of 4.93 million hectares and a production of 5.64 million tons during 2010 (FAOSTAT, 2012). But the average groundnut yield in the country is low (1.14 $\mathrm{t} / \mathrm{ha})$ compared to world average and that of China. The productivity is considered to be low because of number of constraints like abiotic (frequent droughts) and biotic stresses (attacks by pests and diseases).

Among the biotic stresses, foliar fungal diseases are important globally for groundnut (Arachis hypogaea L.). The two major foliar diseases viz., late leaf spot (Phaeoisariopsis personata (Berk. and Curt.) Deighton] and rust (Puccinia arachidis Speg.) are widespread and are economically most important. Yield losses range from 10 to $80 \%$ depending on the severity of the disease and its occurrence in combination with other foliar diseases (Grichar et al., 1998). Use of fungicides to control leaf spots usually increases production costs by $10 \%$ (Coffelt and Porter, 1986). Therefore, adoption of resistant cultivars is the best option as it minimizes losses at farm level and maintains good product quality (Dwivedi et al., 1993). Leaf spot resistant cultivars are also needed because of ever escalating costs of fungicides, their effect on non-target pathogens, and plant injury during application and environmental pollution (Janila et al., 2012).

Thus, deployment of the disease resistance offers several potential benefits beyond direct yield improvement (Chapin et al., 2010). Defoliation, even at low levels, reduces yield, while infection at low levels does not (Smith 1984). Gorbet et al. (1982) proposed that the ultimate value of resistance or tolerance to leaf spots in groundnut was the stabilization of pod yields achieved by minimizing yield losses while reducing fungicide use.Hence, best solution is incorporation of resistance to these diseases into cultivated high yielding varieties is essential.

In breeding programmes aimed at development of foliar disease resistant varieties, it is essential to identify sources of resistance with good breeding potential and to know the genetic control of resistance mechanisms to use appropriate breeding methodologies that would result in isolation of resistant genotypes with high yield potential. Several sources of resistance to late leaf spots have been identified in groundnut (Singh et al., 1997). These genotypes include both wild and cultivated Arachis species and their interspecific derivatives. Screening of 13,000 A. hypogaea accessions at ICRISAT center led to identification of 69 genotypes with resistance to LLS, however resistance was often associated with low yield, poor pod and kernel characteristics and late maturity thus limiting their utility in resistance breeding (Singh et al., 1997). 
Several components (traits) are known to influence resistance to LLS and genetic variability for these components exists in resistant sources (Singh et al., 1997). Sporulation, lesion size, lesion number and latent period are important components that contribute to low field scores of the disease (Aquino et al., 1995). Inheritance of LLS resistance is controlled by simple (Motagi et al., 2000) and multiple recessive genes (Nevill, 1982). Genetic studies with A. hypogaea and interspecific derivatives have indicated predominance of additive gene effects governing resistance to LLS (Jogloy et al., 1987). Estimates of heritability from segregating populations are useful in understanding the genetic consequences of hybridization and inbreeding. They can help the breeder selecting and utilizing superior individuals in a population. In groundnut many studies have been reported to estimate heritability and correlations for different traits but less information on LLS. Sandhu and Khehra (1977) studied heritability of resistance to LLS. In the $F_{3}$ generation of C $501 \times$ AK-12-24 and C $501 \times$ Ah 6595, heritability, genotypic co-efficient of variation and expected genetic advance were high for resistance to $M$. berkeleyi.

Identification of resistant and susceptible lines from the different sources of gene pools is difficult through conventional screening technique because of their co-occurance and defoliating nature of LLS. High levels of resistance to these diseases has been transferred from wild species to cultivars (Reddy et al.,1996 and Moss et al., 1997). Genetic variability is the basic requirement for crop improvement as this provides wider scope for selection. Thus, effectiveness of selection is dependent upon the nature, extent and magnitude of genetic variability present in material and the extent to which it is heritable. Hence, this present study was aimed at i) to assess the variability of important pod yield and yield contributing traits, along with the indices of variability i.e. genotypic coefficient of variation (GCV), phenotypic coefficient of variation (PCV), heritability in broad sense $\left(\mathrm{h}^{2}\right.$ bs ), genetic advance (GA) and genetic advance as per cent of mean (GAM) and ii) to determine the potential lines for high yielding with early maturity and LLS resistant. This study will facilitate an understanding behind expression of character and also role of environment there in.

\section{Materials And Methods}

Material for the present study consisted of 106 recombinant inbred lines (RILs) of the cross JL $24 \times$ ICG 11337 in $8^{\text {th }}$ generation. ICG 11337 is a resistant parent for LLS with high yielding and late maturity. JL 24 is a susceptible parent for LLS with early maturity and wider adoptability. The material was developed at ICRISAT and the experiment was conducted on conserved soil moisture in kharif 2010. These RILs were evaluated along with two parents (JL 24 and ICG 11337) and four checks (one susceptible check, TMV 2 and two resistant checks, ICG 13919 and ICGV 86699 and one moderately resistant check, ICGV 86590). The experiment was laid out in ALPHA design with two replications eight blocks with 14 rows of $3 \mathrm{~m}$ length with a spacing of $60 \mathrm{~cm}$ between the rows and $10 \mathrm{~cm}$ between the plants. Artificial disease epiphytotics was created by using "spreader row technique". TMV 2 susceptible to LLS, hence was planted at every $10^{\text {th }}$ row as well as five rows border around the field to maintain the effective innoculum load. Forty five days after sowing, plants were inoculated uniformly in the evening with the innoculum containing 20,000 conidia/ml water and mixed with Tween $80(0.2 \mathrm{ml} / 1000 \mathrm{ml}$ of water) as a mild surfactant and sprayed on the plants using knapsack sprayer. The weather conditions favoured good development of diseases. High humidity was maintained by irrigating the field in the evening for 30 minutes by sprinkler on rain-free days for 30 days from the day of inoculation. Additional innoculum was provided by placing pots containing diseased plants in the infector row for every $2 \mathrm{~m}$. Rust disease was controlled by spraying calixin $1 \mathrm{ml} /$ litre, while rest of the cultural operations and plant protection measures were followed as per recommended practices ensuring uniform and healthy crop stand. Following observations were recorded from five randomly selected plants viz., days to $50 \%$ flowering, days to maturity, mature pods / plant, total pods / plant, mature seeds / plant, haulm weight / plant, 100- seed weight, shelling \% , LLS disease score at 75, 90 and 102 DAS and pod yield / plant. Data was recorded from The mean values were used for statistical analysis. The data was subjected to analysis of variance (Fisher and Yates 1967). The mean, range, PCV and GCV, heritability and genetic advance were computed following standard statistical procedures.

\section{Results And Discussion}

The RIL population showed highly significant variation for all the traits indicating that the parents are highly diverse (Table1). These observations are in agreement with the findings of Kadam et al. (2007), Khote et al. (2009), Ladole et al. (2009) and Shinde et al. (2010).

Examination of range of expression of the RIL's in respect of the characters studied indicated that the expression of the RILs transcended the limits of the parents for total number of pods / plant, mature pods / plant, 
mature seeds / plant, haulm weight / plant and pod yield / plant. This proves the point that a carefully planned cross can generate high variation. The estimates of GCV and PCV indicated that the values of PCV were always higher than GCV suggesting the influence of environmental factors. Less difference observed between PCV and GCV in certain cases indicated greater role of genetic components and less influence by environment. Similar results were obtained by John et al. (2006), Ladole et al. (2009) and Shinde et al. (2010). In the present investigation, days to $50 \%$ flowering, days to maturity and shelling \% exhibited low magnitudes of GCV and PCV indicating the limited scope of selection for these traits. These observations are in agreement with the findings of Meta (2007), John et al. (2008) and Shinde et al. (2010) for days to $50 \%$ flowering and days to maturity whereas, Savaliya et al. 2009 reported similar results for shelling \% . The GCV and PCV were found to be high for number of mature pods / plant, suggesting wide spectrum of genotypic variation for this trait. Meta (2007) also reported high magnitude of both GCV and PCV for number of mature pods / plant in groundnut. The values of GCV and PCV were high for pod yield / plant. These findings are confirmed by Khote et al. (2009) and Shinde et al. (2010).

The amount of variation generated was quite considerable high for mature seeds / plant, 100- seed weight, LLS score at 75 and haulm weight / plant. Highest estimates of PCV and GCV values for these results are also reported by John et al. (2006) reported for mature seeds / plant and LLS disease score at 70 DAS. John et al. (2008), Khote et al. (2009) and Shoba et al. (2009) earlier reported for haulm weight / plant. Pod yield / plant, mature pods / plant and total pods / plant registered high PCV and moderate GCV values. LLS disease score at 90 and 102 DAS recorded moderate PCV and GCV values. Sawargaonkar et al. (2010) reported similar findings.

Heritability which represents the heritable variation existing in the character was calculated. Days to 50 $\%$ flowering, days to maturity and shelling \% recorded moderate heritability coupled with low genetic advance as per cent of mean, indicate the role of non-fixable genetic variance in the expression of this trait. Similar results reported by Dolma et al., (2010) for days to $50 \%$ flowering, Vijayasekhar (2002) for days to maturity and Venkateshwarlu (2005) for shelling \%. Moderate heritability along with low genetic advance and GCV was observed in the study for days to maturity indicated that this character was largely under the control of nonadditive gene action and selection for this trait would be ineffective.

A relative comparison of heritability estimates and expected genetic advance will give an idea about the nature of gene action governing a particular character. The traits, LLS disease score at 75 DAS, 100- seed weight, haulm weight / plant and LLS disease score at 90 DAS recorded high heritability coupled with high genetic advance as per cent of mean. Mature seeds / plant recorded moderate heritability coupled with high genetic advance as per cent of mean. The result indicate that, these traits are under the control of additive gene action and hence, there is a lot of scope for improvement of these traits in further breeding programmes and single plant selection can be followed for high yielding and LLS disease resistant plants at 75 and 90 in groundnut. These results are similar with the findings of Khedikar (2008) reported for LLS disease score at 70 and 90 DAS , Kavani et al. (2004) and John et al. (2008) for haulm weight / plant, Shinde et al. (2010) reported for 100- seed weight, Khedikar (2008) reported for LLS score at 90 DAS and sound mature kernel per cent was reported earlier by Sawargaonkar et al. (2010). Moderate to high variability, low heritability with moderate genetic advance as per cent of mean was observed for mature pods / plant, total pods / plant and pod yield / plant. The result indicating the prevalence of additive and non-additive gene action. It indicates that these traits for selection will be effective in improving these traits to some extent.

Moderate heritability coupled with low genetic advance as per cent of mean was noticed for days to 50 $\%$ flowering, days to maturity and shelling $\%$. The results indicate the prevalence of narrow range of variability and the presence of non-additive gene action. This suggests limited scope for further improvement of these characters. Similar results were also obtained by Dolma et al. (2010) for days to $50 \%$ flowering and Venkateswarlu, 2005 for shelling \% .

Generally, lines which are potential for one or more character, nevertheless in nature are found occasionally, some genotypes resistant/tolerance to disease. The potential lines with disease score $\leq 4$ at 90 DAS , 103 to 104 days of days to maturity, with $\geq 20$ total number of pods / plant, $\geq 25 \mathrm{~g}$ of 100 - seed weight, $\geq 60$ per cent of shelling and a pod yield / plant of $\geq 10 \mathrm{~g}$ are given in the tables 3 and 4 . . Among these RILs, line no. 100 exhibited significant improvement for disease resistance, early maturing and have highest number of total pods / plant, shelling \%, 100- seed weight and pod yield / plant (Tables 3 and 4). Several lines recorded improvement in at least one of these characters indicating scope for breaking the undesirable association. Thus, potential variability was evident among the crosses for resistance but they were less potential in generating resistant segregants in combination with other desirable traits, revealing a need for raising large segregating population or intermating among the selected segregants. Krishnakanth et al. (2005) reported similar findings in $\mathrm{F}_{5}$ lines for resistance to stem and pod rot in groundnut.

Based on these results, it could be concluded that the selection criteria based on LLS disease score at 75 , 100- seed weight, haulm weight / plant, LLS disease score at 90 , mature pods / plant and total pods / plant 
will serve the purpose of improving pod yield / plant. At the $\mathrm{F}_{8}$ generation the RILs are homozygous where additive and additive $X$ additive genetic variances are fixed and prevailing. Each line of RIL is fixed and does not segregate. The differences observed within a line are environmental, while the differences between lines are an indicative of genetic differences. The best lines are selected and advanced for multi season testing. It should be noted that these are the parameters which are highly correlated with productivity (Sidramappa et al., 2008) and therefore, more information on the nature of variability and its inheritance should be generated for the use to breeders.

The superior lines with good agronomic traits and low disease score can be advanced to yield trials or can be used as parents in breeding programmes.

\section{References}

[1]. Aquino, V.M., Shokes, F.M, Gorbet, D.W and Nutter, F.W. 1995. Late leaf spot progression on peanut as affected by components of partial resistance. Plant Disease, 79: 74-78.

[2]. Chapin, J.W., Thomas, J.S., Isleib, T.G., Shokes, F.M., Branch, W.D. and Tillman, B.L. 2010. Field evaluation of virginia-type peanut cultivars for resistance to tomato spotted wilt virus, late leaf spot and stem rot. Peanut Science, 37: 63-69.

[3]. Dwivedi, S.L., Nigam. S.N., Subrahmanyam, P., Jambunathan, Nagabhushanam, G.V.S., Reddy, P.M., Raghunath, K. and McDonald, D. 1993. Effect of foliar diseases control by Chlorothalonil on pod yield and quality characteristics of confectionery groundnuts (Arachis hypogaea L.). Journal of the Science Food and Agriculture, 63: 265-271.

[4]. FAOSTAT. 2012. Statistical data on crops, groundnut, area, production and productivity of Indi \&world,2012.http://faostat.fao.org/site/567/default.aspx.\#ancor.

[5]. Fisher, R. A. and Yates, F. 1967. Statistical Table for Biological, Agricultural and Medical Research, Oliver and Byod, Publishers, Edinburgh, pp. 18-13.

[6]. Gorbet, D.W., Shokes, F.M. and Jackson, L.F. 1982. Control of peanut leaf spot with a combination of resistance and fungicide treatment. Peanut Science. 9: 87-90.

[7]. Grichar, W.J., Besler, B.A. and Jaks, A.J. 1998. Peanut (Arachis hypogaea L.) cultivar response to leaf spot disease development under four disease management programs. Peanut Science, 25: 35-39.

[8]. Janila, P., Venuprasad, R., Abhishek, R., Aruna, R., Kanaka Reddy, R., Waliyar, F. and Nigam, S.N. 2012. Genetic analysis of resistance to late leaf spot in interspecific groundnuts. Euphytica (Unpublished).

[9]. Jogloy, S., Wynne, J. C and Beute, M. K. 1987. Inheritance of late leaf spot resistance and agronomic traits in peanut. Peanut Science, 14: 86-90.

[10]. John, K., Krishna, K., Vasanthi, T.M., R. P. Ramaiah, M. Venkateswarlu, O. And Naidu, P. H. 2006. Variability studies in groundnut germplasm. Legume Research. 29 (3): 219-220.

[11]. John, K., Vasanthi, R.P., Venkateswarlu, O. Muralikrishna, T. and Naidu P.H. 2008. Genetic analysis and regression studies for yield and yield attributes in $\mathrm{F}_{2}$ segregating population of groundnut crosses. Legume Research, 31 (1): 26-30.

[12]. Kadam, P.S., Desai, D. T., Jagdish, U., Chauhan D. A. and Shelke, B. L. 2007. Variability, heritability and genetic advance in groundnut. Journal of Maharashtra Agricultural Universities, 32(1): 71-73.

[13]. Kavani, R.H., Golakia, P.R., Makne, V.G. and Mandaria, R.B. 2004. Genetic variation and trait association in Valencia groundnut (Arachis hypogaea L.) National symposium: "Enhancing productivity of Groundnut for Sustaining Food and Nutritional security", October 11-13: 27-28.

[14]. Khedikar, Y. P. 2008. Molecular tagging and Mapping of resistance to late leaf spot and rust in groundnut (Arachis hypogaea L.). Ph.D. Thesis. University of Agricultural Science, Dharwad, India.

[15]. Khote, A. C., Bendale, V.W., Bhave S. G. and Patil, P. P. 2009. Genetic variability, heritability and genetic advance in some exotic genotypes of groundnut (Arachis hypogaea L.). Crop Research, 37(1, 2 \& 3) : 186-191.

[16]. Krishnakanth, A., Naidu, G.K. and Gowda, M.V.C. 2005. selection for resistance to stem and pod rot in groundnut (Arachis hypogaea L.). Journal of Oilseeds Research, 22 (1): 226-227.

[17]. Ladole, M. Y., Wakode M. M. and Deshmukh, S. N. 2009. Genetic variability and character association studies for yield and yield contributing traits in groundnut (Arachis hypogaea L.). Journal of Oilseeds Research, 26 (Special Issue) : 123-125.

[18]. Mace, E. S., Phong, D. T., Upadhyaya, H. D., Chandra, S. and Crouch, J. H. 2006. SSR analysis of cultivated groundnut (Arachis hypogaea L.) germplasm resistant to rust and late leaf spot diseases. Euphytica, 152: 317-330.

[19]. Meta, H. R. 2007. Genetic variability, correlation and path coefficient analysis in bunch groundnut (Arachis hypogaea L.). M.Sc. (Ag.) Thesis, submitted to the Junagadh Agricultural University, Junagadh.

[20]. Moss, J.P., Singh, A. K., Reddy, L. J., Nigam, S. N., Subrahmanyam, P., McDonald, D. and Reddy, A.G.S. 1997. Registration of ICGV 87165 peanut germplasm with multiple resistance. Crop Science, 37: 1028.

[21]. Motagi, B. N, Gowda, M.V.S. and Naidu. G.K. 2000. Inheritance of late leaf spot resistance in groundnut mutants. Indian Journal of Genetics, $\mathbf{6 0}(3)$ : 347-352.

[22]. Mothilal, A., Nallathambi G. and Sankara Pandian, R. 2004. Genetic variability in confectionery groundnut (Arachis hypogaea L.) genotypes. National Symposium: Enhancing Productivity of Groundnut for Sustaining Food and Nutritional Security. NRCG, Junagadh. Oct. 11-12, 2004, 7-9.

[23]. Reddy, L. J., Nigam, S. N., Moss, J. P., Singh, A. K., Subrahmanyam, P., McDonald, D. and Reddy, A.G.S. 1996. Registration of ICGV86699 peanut germplasm line with multiple disease and insect resistance. Crop Science, $36: 821$.

[24]. Sandhu, B.H. and Khehra, A.S. 1977. Inter-relationships on semi-spreading $\times$ bunch and semi-spreading $\times$ semi-spreading crosses of groundnut. Indian Journal of Genetics and Plant Breeding, 37: 22-26.

[25]. Savaliya, J. J., Pansuriya, A. G., Sodavadiya, P. R. and Leva, R. L. 2008. Character association study in interspecific and intraspecific hybrid derivatives of groundnut (Arachis hypogaea L.). under high dose of fertilizers. International Journal of Bioscience reporter, 185-188.

[26]. Sawargaonkar, S.L., Giri, R.R. and Hudge, B.V. 2010. Character association and path analysis of yield component traits and late leaf spot disease traits in groundnut (Arachis hypogaea L.). Agricultural Science Digest. 30(2): 115 - 119.

[27]. Shinde, P. P., Khanpara, M. D., Vachhani, J. H., Jivani, L. L. and Kachhadia, V. H. 2010. Genetic variability in virginia bunch groundnut (Arachis hypogaea L.). Plant Archives, 10 (2): 703-706.

[28]. Shoba, D., Manivannan, N. and Vindhiyavarman, P. 2009. Studies on variability, heritability and genetic advance in groundnut (Arachis hypogaeae L.). Electronic Journal of Plant Breeding, 1: 74-77. 
[29]. Sidramappa, S. A., Patil, P., Salimath, M. and Kajjidoni, S. T. 2008. Genetic variation for productivity and its related traits in a recombinant inbred lines population of chickpea. Karnataka Journal Agricultural Science, 21(4): 488-490.

[30]. Singh, A. K., Mehan, V. K. and Nigam, S. N. 1997. Sources of resistance to groundnut fungal and bacterial diseases: An update and appraisal. Information Bulletin No. 50. International Crops Research Institute for the Semi Arid Tropics, Patancheru, Andhra Pradesh, India, p. 48

[31]. Smith, D. H.1984. Foliar diseases-early and late leaf spots. In: Porter, D.M. Smith, D.H. and Rodriguez-Kabana R. (ed) Compendium of Peanut Diseases. American Phytopathological Society. 5-7.

[32]. Venkataramana, P. 2001. Variability and correlation studies in groundnut. Crop Reserach, 21: 81-83.

[33]. Venkateshwarlu, O. 2005. Genetic analysis of physiological and yield attributes related to drought tolerance in Groundnut (Arachis hypogaea L.). Ph.D. Thesis. Acharya N.G. Ranga Agricultural University, Hyderbad, India.

[34]. Vijayasekhar, C. 2002. Genetic divergence studies through $D^{2}$ statistic and isozyme analysis in spanish bunch groundnut (Arachis hypogaea L.). M. Sc. (Ag.). Thesis. Acharya N.G. Ranga Agricultural University, Hyderbad, India.

Table 1. Analysis of variance (mean squares) for agronomic traits and late leaf spot in RIL population of a groundnut

\begin{tabular}{|c|c|c|c|c|c|c|c|c|c|c|c|c|c|}
\hline Source & $\begin{array}{c}\text { DO } \\
\text { F } \\
\end{array}$ & DFF & DM & MPD & TPD & MSD & HSW & SH & HUW & $\begin{array}{c}\text { DS } \\
75\end{array}$ & $\begin{array}{c}\mathrm{DS}^{-} \\
90\end{array}$ & $\begin{array}{c}\text { DS_1 } \\
02\end{array}$ & PYD \\
\hline Blocks & 14 & 0.74 & 12.12 & 12.33 & 15.49 & 27.69 & 13.44 & 6.15 & 11.19 & $\begin{array}{c}0.38 \\
* *\end{array}$ & 0.31 & 0.36 & 4.69 \\
\hline $\begin{array}{l}\text { Genotyp } \\
\text { es }\end{array}$ & 111 & $\begin{array}{c}3.52 \\
* *\end{array}$ & $\begin{array}{c}87.91 \\
* *\end{array}$ & $\begin{array}{c}23.31 \\
* *\end{array}$ & $\begin{array}{c}27.57 \\
* *\end{array}$ & $\begin{array}{c}71.06^{*} \\
*\end{array}$ & $\begin{array}{c}61.36 \\
* *\end{array}$ & $\begin{array}{c}16.82 \\
* *\end{array}$ & $\begin{array}{c}66.83 * \\
*\end{array}$ & $\begin{array}{c}0.87 \\
* *\end{array}$ & $\begin{array}{c}0.96 \\
* *\end{array}$ & $\begin{array}{c}1.58 * \\
*\end{array}$ & $12.35^{*}$ \\
\hline Error & -- & $\begin{array}{l}1.44 \\
(97)\end{array}$ & $\begin{array}{c}23.48 \\
(97)\end{array}$ & $\begin{array}{c}15.30 \\
(87)\end{array}$ & $\begin{array}{c}17.30 \\
(87)\end{array}$ & $\begin{array}{c}40.34 \\
(87)\end{array}$ & $\begin{array}{c}11.25 \\
(87)\end{array}$ & $\begin{array}{l}6.85 \\
(83)\end{array}$ & $\begin{array}{c}14.17 \\
(95)\end{array}$ & $\begin{array}{l}0.11 \\
(97)\end{array}$ & $\begin{array}{l}0.19 \\
(97)\end{array}$ & $\begin{array}{l}0.28 \\
(97)\end{array}$ & $\begin{array}{l}8.41 \\
(93)\end{array}$ \\
\hline
\end{tabular}

\section{cross JL $24 \times$ ICG 11337}

DFF - Days to $50 \%$ flowering

- Total pods / plant

MSD - Mature seeds / plant

- Haulm weight / plant (g)

DS-75 - LLS score at 75 days after sowing

DS 102 - LLS score at 102 days after sowing

PYD - Pod yield / plant (g)

** Significant at $\mathrm{P} \leq 0.01$,

DOF - Degrees of freedom

NS - Non significant

Values in paranthesis indicates error degrees of freedom
MPD - Mature pods / plant

TPD

SH - Shelling \%

HUW

Table 2. Estimation of mean, range, components of variance, heritability (broad sense) and genetic advance as per cent of mean in different traits in groundnut

\begin{tabular}{|c|c|c|c|c|c|c|c|c|c|}
\hline \multirow[t]{2}{*}{ Character } & \multirow[t]{2}{*}{ Min } & \multirow[t]{2}{*}{ Max } & \multicolumn{3}{|c|}{ Mean } & \multirow{2}{*}{$\begin{array}{l}\text { PCV } \\
(\%)\end{array}$} & \multirow{2}{*}{$\begin{array}{l}\text { GCV } \\
(\%)\end{array}$} & \multirow{2}{*}{$\begin{array}{l}\text { Heritability } \\
\left(\mathbf{h}^{2}\right) \%\end{array}$} & \multirow{2}{*}{$\begin{array}{l}\text { GAM } \\
(\%)\end{array}$} \\
\hline & & & $\mathbf{P}_{1}$ & $\mathbf{P}_{2}$ & Population & & & & \\
\hline DFF & 29 & 34 & 31 & 35 & 31 & 5.16 & 3.41 & 43.53 & 4.63 \\
\hline DM & 101 & 125 & 103 & 124 & 109 & 7.00 & 5.39 & 59.43 & 8.57 \\
\hline MPD & 3 & 23 & 12 & 16 & 12 & 37.07 & 17.66 & 22.69 & 17.33 \\
\hline TPD & 4 & 24 & 15 & 18 & 14 & 35.57 & 17.78 & 24.98 & 18.30 \\
\hline MSD & 5 & 38 & 19 & 24 & 18 & 41.23 & 22.55 & 29.92 & 25.41 \\
\hline HSW & 10.82 & 44.64 & 21.67 & 31.25 & 26.44 & 23.72 & 20.05 & 71.40 & 34.89 \\
\hline SH (\%) & 54.40 & 67.54 & 61.50 & 62.72 & 61.13 & 5.80 & 3.91 & 45.46 & 5.43 \\
\hline HUW & 6.27 & 41.89 & 12.07 & 29.66 & 16.77 & 38.89 & 31.76 & 66.69 & 53.43 \\
\hline DS_ 75 & 1 & 5 & 4 & 2 & 3 & 25.88 & 22.97 & 78.75 & 41.98 \\
\hline DS 90 & 4 & 7 & 7 & 4 & 5 & 15.10 & 12.49 & 68.41 & 21.28 \\
\hline DS_102 & 6 & 9 & 9 & 6 & 8 & 12.73 & 10.77 & 71.59 & 18.78 \\
\hline PYD & 2.32 & 14.64 & 8.07 & 13.50 & 7.96 & 40.80 & 18.38 & 20.28 & 17.05 \\
\hline
\end{tabular}

$\mathrm{P}_{1}-\mathrm{JL} 24$, $\mathrm{P}_{2}-$ ICG 11337

DFF - Days to $50 \%$ flowering

DM - Days to maturity

MPD - Mature pods / plant

TPD - Total

pods / plant

MSD - Mature seeds / plant

HSW - 100- seed weight (g)

Haulm weight / plant $(\mathrm{g})$

DS-75 - LLS disease score at 75 days after sowing

DS-102 - LLS disease score at 102 days after sowing

SH - Shelling \%

HUW -

DS-90 - LLS disease score at 90 days after sowing PYD - Pod yield / plant (g) 
Table 3. Superior recombinant lines with resistance to late leaf spot and

productivity parameters in RIL population of the cross JL $24 \times$ ICG 11337 .

\begin{tabular}{|l|l|l|}
\hline Trait combination & No. of superior lines & Line no. \\
\hline $\begin{array}{l}\text { Early maturity + total pods / plant + 100- seed weight }+ \\
\text { shelling \% + pod yield / plant+ disease resistance }\end{array}$ & 1 & 100 \\
\hline Total pods / plant + pod yield / plant + disease resistance & 2 & 75 and 100 \\
\hline Early maturity + pod yield / plant + disease resistance & 4 & $17,75,97$ and 100 \\
\hline $100-$ seed weight + shelling \% + disease resistance & 3 & 13,47 and 100 \\
\hline Pod yield +100- seed weight + shelling \% + disease resistance & 3 & 75,97 and 100 \\
\hline Pod yield / plant + disease resistance & 4 & $17,75,97$ and 100 \\
\hline
\end{tabular}

Table 4. Superior lines with productivity parameters and resistance to late leaf spot in RIL population of the cross JL 24 × ICG 11337.

\begin{tabular}{|l|l|l|l|l|l|l|l|l|l|l|l|}
\hline $\begin{array}{l}\text { Line } \\
\text { no. }\end{array}$ & DFF & DM & MPD & TPD & MSD & HSW & SH & HUW & PYD & DS_75 & DS_90 \\
\hline 13 & 34 & 125 & 8 & 9 & 15 & 33.73 & 64.27 & 19.19 & 8.52 & 2 \\
\hline 17 & 29 & 103 & 17 & 22 & 17 & 35.69 & 57.28 & 18.74 & 11.64 & 2 \\
\hline 47 & 32 & 118 & 13 & 13 & 18 & 31.79 & 61.30 & 15.15 & 9.59 & 1 & 4 \\
\hline 75 & 31 & 103 & 18 & 19 & 33 & 22.64 & 61.88 & 21.41 & 12.11 & 2 \\
\hline 90 & 32 & 116 & 9 & 10 & 11 & 32.91 & 55.84 & 22.69 & 7.43 & 2 & 4 \\
\hline 97 & 30 & 104 & 14 & 16 & 18 & 31.88 & 58.84 & 22.96 & 10.24 & 2 \\
\hline 100 & 29 & 103 & 21 & 21 & 33 & 28.28 & 62.09 & 14.66 & 14.55 & 2 \\
\hline
\end{tabular}

DFF-Days to 50 per cent flowering TPD-Total pods / plant

SH-Shelling \%

DS-75 LLS disease score at 75 DAS
DM-Days to maturity MSD-Mature seeds / plant PYD-Pod yield / plant (g) DS 90-LLS score at 90 DAS
MPD-Mature pods / plant HSW-100- seed weight (g) 